\title{
Article \\ Gastric Serotonin Biosynthesis and Its Functional Role in L-Arginine-Induced Gastric Proton Secretion
}

\author{
Ann-Katrin Holik ${ }^{1,+}$, Kerstin Schweiger 1,+ ${ }^{+}$, Verena Stoeger ${ }^{2}$, Barbara Lieder 1,2 ${ }^{\mathbb{D}}$, Angelika Reiner ${ }^{3}$, \\ Muhammet Zopun ${ }^{1}$, Julia K. Hoi ${ }^{2}$, Nicole Kretschy ${ }^{4}$, Mark M. Somoza ${ }^{4,5,6} \mathbb{D}^{\mathbb{D}}$, Stephan Kriwanek ${ }^{7}$, \\ Marc Pignitter ${ }^{1}$ (D) and Veronika Somoza $1,2,6,8, *$
}

\section{check for}

updates

Citation: Holik, A.-K.; Schweiger, K. Stoeger, V.; Lieder, B.; Reiner, A.; Zopun, M.; Hoi, J.K.; Kretschy, N.; Somoza, M.M.; Kriwanek, S.; et al. Gastric Serotonin Biosynthesis and Its Functional Role in L-Arginine-Induced Gastric Proton Secretion. Int. J. Mol. Sci. 2021, 22, 5881. https://doi.org/ $10.3390 /$ ijms22115881

Academic Editor: Lukas J.A.C. Hawinkels

Received: 11 April 2021

Accepted: 26 May 2021

Published: 30 May 2021

Publisher's Note: MDPI stays neutral with regard to jurisdictional claims in published maps and institutional affiliations.

Copyright: (c) 2021 by the authors. Licensee MDPI, Basel, Switzerland. This article is an open access article distributed under the terms and conditions of the Creative Commons Attribution (CC BY) license (https:/ / creativecommons.org/licenses/by/ $4.0 /)$.
1 Department of Physiological Chemistry, Faculty of Chemistry, University of Vienna, Althanstraße 14, 1090 Vienna, Austria; ann-katrin.holik@univie.ac.at (A.-K.H.); kerstin.schweiger@univie.ac.at (K.S.); barbara.lieder@univie.ac.at (B.L.); muhammet.zopun@univie.ac.at (M.Z.); marc.pignitter@univie.ac.at (M.P.)

2 Christian Doppler Laboratory for Bioactive Aroma Compounds, Faculty of Chemistry, University of Vienna, Althanstraße 14, 1090 Vienna, Austria; verena.stoeger@univie.ac.at (V.S.); julia.katharina.hoi@univie.ac.at (J.K.H.)

3 Pathologisch-Bakteriologisches Institut, Sozialmedizinisches Zentrum Ost- Donauspital, Langobardenstraße 122, 1220 Vienna, Austria; angelika.reiner@wienkav.at

4 Department of Inorganic Chemistry, Faculty of Chemistry, University of Vienna, Althanstraße 14, 1090 Vienna, Austria; Nicole.kretschy@univie.ac.at (N.K.); mark.somoza@univie.ac.at (M.M.S.)

5 Food Chemistry and Molecular Sensory Science, Technical University of Munich, Lise-Meitner-Straße 34, 85354 Freising, Germany

6 Leibniz Institute for Food Systems Biology, Technical University of Munich, Lise-Meitner-Str. 34, 85345 Freising, Germany

7 Chirurgische Abteilung, Sozialmedizinisches Zentrum Ost- Donauspital, Langobardenstraße 122, 1220 Vienna, Austria; stefan.kriwanek@wienkav.at

8 Nutritional Systems Biology, School of Life Sciences, Technical University of Munich, Lise-Meitner-Str. 34, 85345 Freising, Germany

* Correspondence: veronika.somoza@univie.ac.at; Tel.: +431-4227-70601; Fax: +431-4277-9706

+ Contributed equally to this work.

Abstract: Among mammals, serotonin is predominantly found in the gastrointestinal tract, where it has been shown to participate in pathway-regulating satiation. For the stomach, vascular serotonin release induced by gastric distension is thought to chiefly contribute to satiation after food intake. However, little information is available on the capability of gastric cells to synthesize, release and respond to serotonin by functional changes of mechanisms regulating gastric acid secretion. We investigated whether human gastric cells are capable of serotonin synthesis and release. First, HGT-1 cells, derived from a human adenocarcinoma of the stomach, and human stomach specimens were immunostained positive for serotonin. In HGT-1 cells, incubation with the tryptophan hydroxylase inhibitor p-chlorophenylalanine reduced the mean serotonin-induced fluorescence signal intensity by $27 \%$. Serotonin release of $147 \pm 18 \%$, compared to control HGT-1 cells (set to $100 \%$ ) was demonstrated after treatment with $30 \mathrm{mM}$ of the satiating amino acid L-Arg. Granisetron, a 5-HT3 receptor antagonist, reduced this L-Arg-induced serotonin release, as well as L-Arg-induced proton secretion. Similarly to the in vitro experiment, human antrum samples released serotonin upon incubation with $10 \mathrm{mM}$ L-Arg. Overall, our data suggest that human parietal cells in culture, as well as from the gastric antrum, synthesize serotonin and release it after treatment with L-Arg via an HTR3-related mechanism. Moreover, we suggest not only gastric distension but also gastric acid secretion to result in peripheral serotonin release.

Keywords: human gastric tumor cells; gastric serotonin release; immunofluorescence; proton secretion; energy metabolism 


\section{Introduction}

Within the central nervous system (CNS), the monoamine serotonin (5-HT), synthesized from the essential amino acid L-tryptophan, is an important neurotransmitter associated with a manifold of different disorders, such as schizophrenia [1] and depression [2-4], but is also known to regulate pathways of satiation [5-7]. Although central $5-\mathrm{HT}$ is believed to play a pivotal role in satiation, peripherally administered 5-HT had already been demonstrated to reduce food intake back in the early 1980s [8]. Moreover, our own recent human intervention trials demonstrated peripheral serotonin to correlate with energy intake and gastric emptying [9-12].

The hypothesis of peripheral 5-HT regulating mechanisms of satiation is supported by large quantities being synthesized in enterochromaffin cells of the gastrointestinal (GI) tract [13], which is chiefly involved in mechanisms regulating food intake. In the duodenum, activation of 5-HT receptors, e.g., the 5-HT3, regulates not only emetic pathways but also gastric motility, intestinal secretion and visceral sensitivity [14-16]. 5-HT is thought to mostly act locally, stimulating and sensitizing abdominal vagal nerve terminals which project to the brainstem; although under some circumstances, plasma concentrations of 5-HT may also be increased sufficiently to pass through the blood-brain barrier [17]. Peripheral serotonin released into the circulation upon gastric distension has been shown to stimulate c-fos expression in specific brain nuclei via 5-HT3 receptors in conscious rats, indicating a satiating potential of peripheral serotonin, as well [18].

Choi et al. [19] carried out investigations into the distribution of 5-HT in different cell lineages of three healthy human donor stomachs. Their analysis revealed distinct patterns of endocrine cells, showing 5-HT-positive cells in the proximal stomach and in the antrum. In addition, the 5-HT transporter (SERT) was identified in the antrum.

From a functional point of view, gastric 5-HT might not only contribute to satiation by its response to food-induced gastric distension [18]. In this study, we hypothesize a satiating role for gastric 5-HT on gastric acid secretion that is different from the secretory effects of 5-HT released by enteroendocrine cells in the duodenum. Whereas in the duodenum, a hydrochloric acid-induced release of 5-HT has been shown to inhibit gastric acid secretion [20,21], an increase of gastric acid secretion as a response to food intake might result in gastric 5-HT release which, in turn, contributes to satiation [22]. This hypothesis is supported by findings showing that gastric acid secretion was associated with delayed gastric emptying of a protein-rich meal, and reduced subsequent food intake in cats that received intravenous bombesin [23], a peptide hormone that has been shown to reduce food intake in lean subjects [24].

From a mechanistic point of view, several cell line models have been studied to identify the cellular pathways by which 5-HT is synthesized, degraded and released in response to food ingredients by various cell types, such as neuroblastoma cells (SH-SY5Y) [25], enterochromaffin cells (QGP-1) [26] and the human colon carcinoma cell line Caco-2 [27-29]. Since we hypothesize a functional role of gastric 5-HT in gastric acid secretion, we first aimed at investigating the capacity of a stomach-derived cell line model, the human gastric tumor cells (HGT-1), to synthesize and release serotonin after nutrient stimulation, verify L-arginine (L-Arg)-induced serotonin secretion in human antrum specimens, and to investigate serotonin's functional role in proton secretion as a pivotal mechanism of gastric acid secretion as a satiety signal.

The human gastric cell line HGT-1 was established from a poorly differentiated adenocarcinoma on the posterior wall of the body of a patient's stomach by Laboisse and co-workers in 1982 [30]. HGT-1 cells have been shown to express histamine $\mathrm{H}_{2}$ receptors, which have been demonstrated to mediate adenylyl cyclase activation and cAMP production [30]. Furthermore, this cell line has been shown to express acetylcholine receptors, the $\mathrm{H}^{+} / \mathrm{K}^{+}$ATPase proton pump, an omeprazol-binding site possessing a $\mathrm{K}^{+}$ channel [31], angiotensin 1-converting enzyme [32], and transporters required for gastric acid secretion [33]. HGT-1 cells have consequently been established as a valuable cell model for assessing the effects of different food constituents, found, e.g., in coffee beverages, on 
proton secretion by measuring the intracellular $\mathrm{pH}$ value [34,35]. Here, we demonstrate this cell model's capacity to synthesize serotonin and its subsequent secretion in response to exogenous stimuli, by incubating with L-Arg, an amino acid which has recently been reported to reduce food intake [11,36], delay and inhibit gastric emptying, and enhance gastric adaptive relaxation [37]. As 5-HT3 receptors have been suggested to be involved in gastric acid release [22], and initial experiments of this work demonstrated that HGT-1 cells are capable of proton secretion, we carried out co-incubation experiments with the 5-HT3 inhibitor granisetron [38]. Finally, serotonin release induced by L-Arg was confirmed in human antrum samples. With these results, we demonstrate that gastric serotonin not only regulates gastric emptying but also mechanisms of gastric acid secretion as key determinants of satiation targeted by dietary constituents.

\section{Results}

\subsection{Cell Viability}

The viability of HGT- 1 cells was assessed using the MTT assay. None of the treatments led to a decrease in the metabolic activity $(80 \%$, Figure S1) of HGT-1 cells compared to the corresponding control (KRPH).

\subsection{Serotonin Release}

The serotonin-sensitive ELISA detected serotonin in the supernatants collected from cells treated with Krebs-Ringer-HEPES buffer $(+0.1 \%$ ascorbic acid). As presented in Figure S2, serotonin release was the highest in HGT-1 cell line (1.25 $\pm 0.5 \mathrm{pg} / \mathrm{cell})$ in comparison to Caco-2 cells $(0.02 \pm 0.01 \mathrm{pg} /$ cell $)$ and QGP-1 cells $(0.03 \pm 0.01 \mathrm{pg} / \mathrm{cell})$. Serotonin concentrations were corrected for cell number and incubation volume. Cell number was evaluated using a Neubauers' cell counting chamber.

\subsection{Serotonin Biosynthesis}

Protein expression of aromatic amino acid decarboxylase (AADC) was tested by the capability of cellular lysate to react to 5-HTP provided in excess to serotonin. This experiment showed a rise in the determined serotonin with increasing 5-HTP concentrations (Figure 1). From this graph, a Lineweaver-Burk plot was derived, which led to a value of $0.28 \mathrm{mM}$ for $\mathrm{Km}$ and $85 \mathrm{nmol} \mathrm{mg}$ protein- $1 \mathrm{~h}-1$ for $\mathrm{v}_{\max }$.

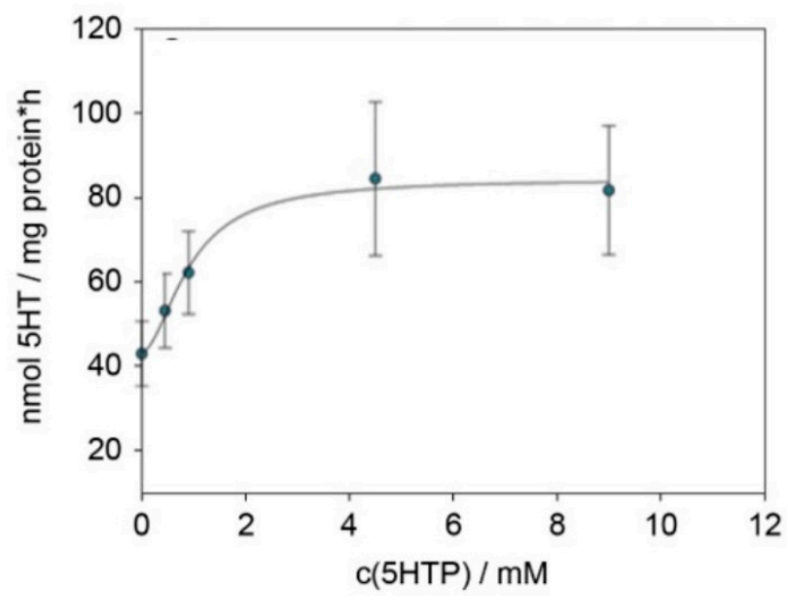

Figure 1. Graph of the serotonin formed in HGT-1 cells, normalized to protein concentration and incubation time vs. the substrate concentration. Data were collected from 3-4 biological replicates with 1-2 technical replicates.

\subsection{Serotonin Staining}

Figure 2 shows a typical result of HGT- 1 cells stained using an anti-serotonin antibody, whereas Figure S3 displays an additional HGT-1 fluorescence staining experiment using another antibody. 


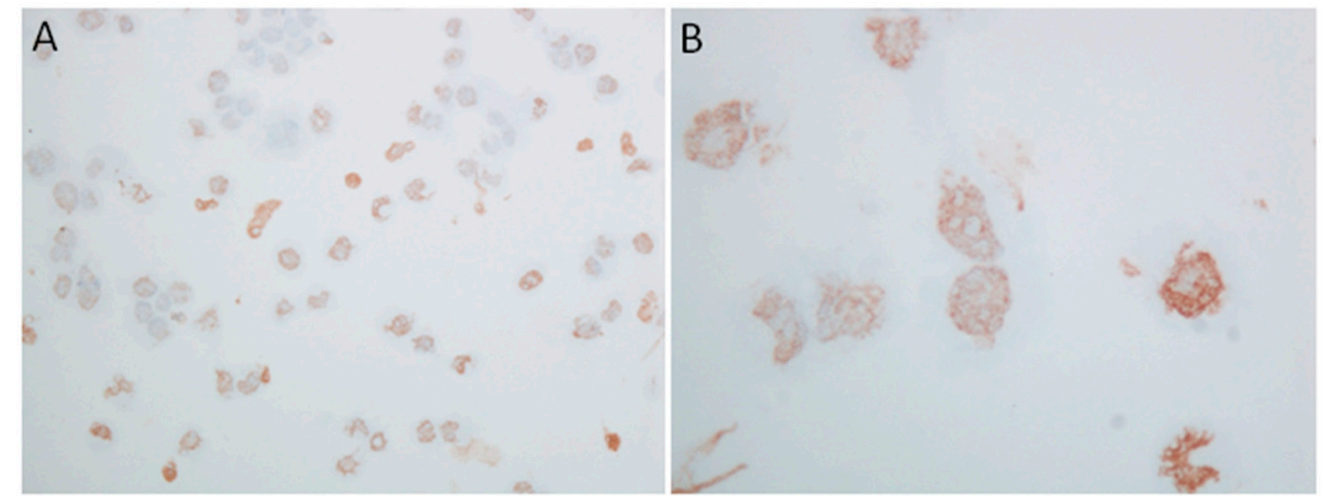

Figure 2. Immunohistochemical staining for serotonin in HGT-1 cells. (A) Original magnification $\times 200$; (B) original magnification $\times 600$.

In a second set of experiments, HGT-1 cells were seeded into either DMEM or DMEM containing $100 \mu \mathrm{M}$ PCPA. In both cases, positive serotonin staining was observed (Figure S3). However, cells that received PCPA at seeding exhibited less pronounced serotonin staining (Figure S3E). After image analysis with Image J, a fold-change of 0.73 was calculated, indicating a reduction in serotonin staining by $27 \%$ in the $p$-chlorophenylalanine (PCPA) treated group. In the absence of a blocking peptide, the primary anti-5-HT antibody was pre-incubated with pure serotonin for $30 \mathrm{~min}$ prior to the incubation. In this experiment, control cells receiving the pre-blocked version of the antibody showed a mean reduction in serotonin staining by $23 \%$, suggesting that part of the antibody was prevented from binding to cellular serotonin by the pre-incubation. Figure 3 shows characteristic staining for serotonin in human benign and carcinoma stomach samples with positivity in scattered single cells.
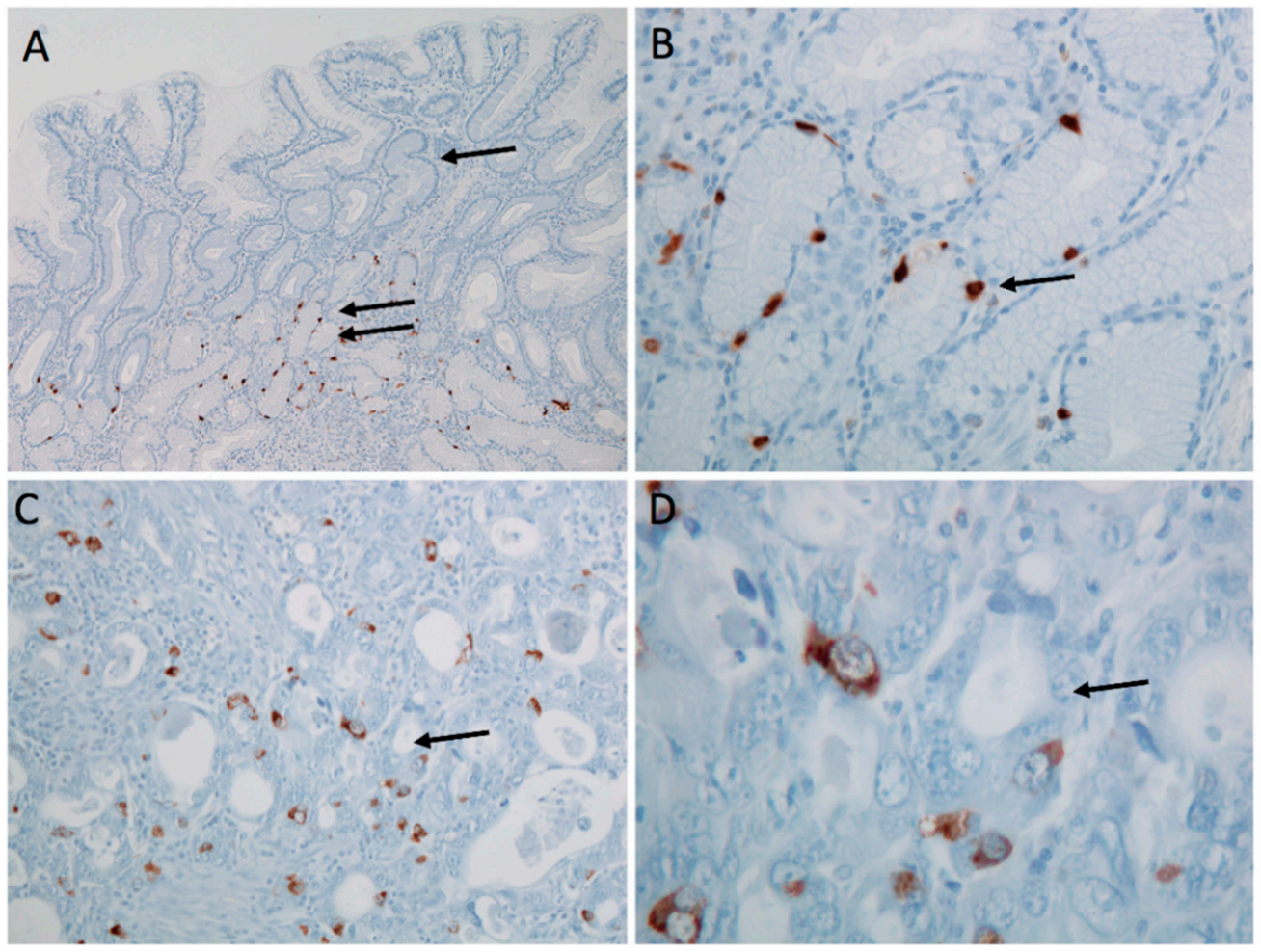

Figure 3. Immunohistochemical staining for serotonin in human stomach samples. Gastric antral mucosa demonstrating cytoplasmic reactivity in scattered individual enterochromaffin-like cells within gastric glands; overview (A); detail (B). Gastric adenocarcinoma with cytoplasmic reactivity in scattered individual carcinoma cells; overview (C); detail (D). Original magnification: $(\mathbf{A}) \times 100$; $(B, C) \times 200 ;(D) \times 600$. 


\subsection{Effects of L-Arg on Gene Expression, Serotonin Release, Proton Release and Gastric Motility} 2.5.1. Gene Expression

First, the effects of $50 \mathrm{mM}$ L-Arg on the gene expression of HGT-1 cells were assessed in a genome-wide screening using customized cDNA microarrays. The concentration of $50 \mathrm{mM}$ L-Arg was based on previous results showing an induction of protein secretion in HGT-1 cells [39]. The scatter plot shown in Figure S4 shows a broad distribution of regulated probes, suggesting a strong impact of L-Arg treatment on gene expression. Pathway analysis using the Database for Annotation, Visualization and Integrated Discovery (DAVID) [40] suggested the expression of serotonin receptors being altered (Table 1A,B). As a result, we first assessed the expression of $H T R 1 A, 2 A, 1 B, 3 A, 3 B, 3 C, 3 D, 3 D, 4$ and 7 , in addition to the genes encoding the enzymes required in serotonin synthesis and the serotonin reuptake transporter SERT, encoded by SLC6A4. This showed SLC6A4, TPH1, TPH2, HTR3C, HTR3D and HTR7 to be consistently expressed over $4-5$ biological replicates. However, HTR1B, HTR3B and HTR3E were only detectable in some of the samples. HTR1A, HTR2A, HTR3A and HTR4 were detected in none of the samples tested. Treatment of HGT-1 cells with L-Arg for $3 \mathrm{~h}$ regulated the gene expression of SLC6A4, TPH2, HTR3C and HTR7 (Table 2).

Table 1. Clusters generated by DAVID functional annotation software using microarray data gathered from HGT-1 cells exposed to DMEM or DMEM supplemented with L-Arg for $3 \mathrm{~h}$.

\begin{tabular}{ccc} 
A: Cluster 1, Enrichment Score: $\mathbf{3 . 4 1}$ & & \\
& $p$-Value & Benjamini \\
disulfide bonds & $1.14 \times 10^{-5}$ & $3.75 \times 10^{-3}$ \\
glycoproteins & $4.90 \times 10^{-4}$ & $3.30 \times 10^{-2}$ \\
glycosylation site: N-linked & $1.00 \times 10^{-3}$ & $2.80 \times 10^{-1}$ \\
signal peptides & $1.90 \times 10^{-3}$ & $3.90 \times 10^{-1}$ \\
B: Cluster 2, Enrichment Score: $\mathbf{3 . 1 4}$ & & \\
p-Value & Benjamini \\
serotonin receptor signaling pathway & $2.30 \times 10^{-7}$ & $4.60 \times 10^{-4}$ \\
G-protein coupled serotonin receptor activity & $2.30 \times 10^{-6}$ & $1.30 \times 10^{-3}$ \\
serotonin binding & $5.00 \times 10^{-5}$ & $1.40 \times 10^{-2}$ \\
serotonergic synapse & $1.70 \times 10^{-4}$ & $1.30 \times 10^{-2}$ \\
5-hydroxytryptamine receptor family & $8.10 \times 10^{-4}$ & $4.90 \times 10^{-1}$ \\
neurotransmitter receptor activity & $2.70 \times 10^{-3}$ & $3.10 \times 10^{-1}$ \\
release of sequestered calcium ion into cytosol & $1.50 \times 10^{-2}$ & $8.90 \times 10^{-1}$ \\
adenylate cyclase-inhibiting G-protein coupled receptor signaling pathway & $2.40 \times 10^{-2}$ & $9.20 \times 10^{-1}$ \\
vasoconstriction & $5.80 \times 10^{-2}$ & $9.60 \times 10^{-1}$ \\
dendrite & $2.10 \times 10^{-1}$ & $9.30 \times 10^{-1}$ \\
\hline
\end{tabular}

Table 2. qPCR data obtained after treating HGT-1 cells with $30 \mathrm{mM}$ L-Arg for $3 \mathrm{~h}$. Data are shown as average \pm SEM. $n=4-5$, $\operatorname{tr}=2-3$; statistics: Mann-Whitney rank-sum test.

\begin{tabular}{cccc}
\hline & Control & L-Arg & $p$-Value \\
\hline TPH1 & $1.00 \pm 0.04$ & $1.50 \pm 0.16$ & 0.078 \\
TPH2 & $1.00 \pm 0.11$ & $10.0 \pm 2.0$ & $<0.001$ \\
SLC6A4 & $1.00 \pm 0.05$ & $10.8 \pm 1.2$ & $<0.001$ \\
HTR7 & $1.00 \pm 0.06$ & $2.88 \pm 0.57$ & 0.034 \\
HTR3D & $1.00 \pm 0.11$ & $2.83 \pm 0.75$ & 0.138 \\
HTR3C & $1.00 \pm 0.09$ & $2.62 \pm 0.45$ & $<0.001$ \\
\hline
\end{tabular}

\subsubsection{Serotonin Release}

Figure S5A shows a chromatogram of the supernatant collected from HGT-1 cells. Both L-Trp and 5-HT were detected in the supernatant, whereas the 5-HTP concentration was too low to be detected by LC-MS/MS. However, incubation of HGT-1 cells with $30 \mathrm{mM}$ L-Arg increased the serotonin concentration in the cellular supernatant to $147 \pm 18 \%$, compared to cells treated with KRHB only ( $+0.1 \%$ ascorbic acid; Figure S5B). This result was obtained by means of an ELISA, and verified by LC-MS/MS analysis, where an increase to $162 \pm 48 \%$ was detected (Figure S5C). No significant difference between the neutral $\mathrm{pH}$ control and 
the control adjusted to $\mathrm{pH} 9.5$ was found. Similarly, no difference between L-Arg simply added to KRHB and the $\mathrm{pH}$-adjusted L-Arg solution was detected (data not shown).

In the experiment using $10 \mu \mathrm{M}$ granisetron, the L-Arg-induced serotonin release was prevented by the 5-HT3 antagonist, reducing the increase from $124 \pm 23 \%$, observed after L-Arg treatment, to $95 \pm 16 \%$, compared to the control set to $100 \%(p<0.05)$. Granisetron alone did not affect the serotonin release compared to control cells treated with KRHB only (Figure 4).

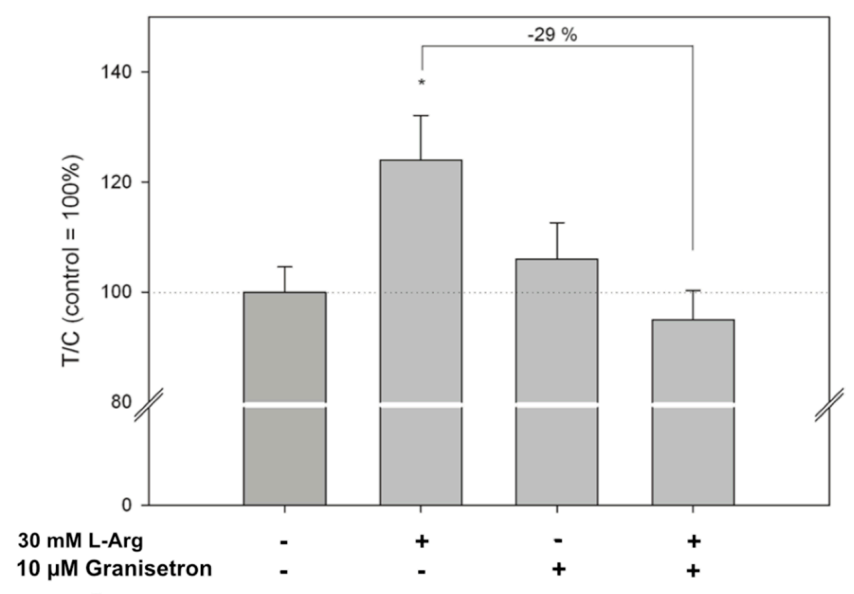

Figure 4. Influence of $10 \mu \mathrm{M}$ of the 5-HT3 receptor antagonist granisetron on L-Arg-induced serotonin release by HGT-1 cells. Data are shown as average \pm standard deviation of treated over control (T/C) samples, with data from L-Arg-treated cells set to $100 \%(\mathrm{~T} / \mathrm{C}=100 \%) . n=3-4$, $\mathrm{tr}=2$; statistics: one-way ANOVA vs. control followed by Holm-Sidak post hoc test $(*: p<0.05)$.

\subsubsection{Serotonin Release in Human Antrum Samples}

Figure 5 shows the serotonin release from human gastric antrum samples derived from gastric sleeve surgery. When incubated with L-Arg, a concentration of $10 \mathrm{mM}$, although neither 30 nor $50 \mathrm{mM}$, L-Arg stimulated the release of serotonin from gastric tissue by $44 \pm 7 \%(p<0.05)$.

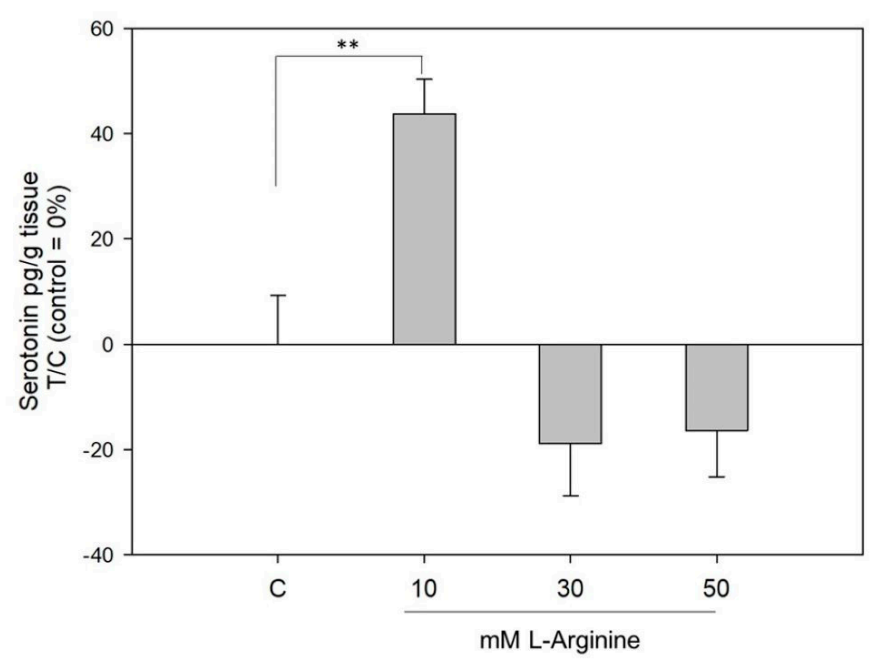

Figure 5. Impact of L-Arg on serotonin release in human gastric tissue. Data are presented as mean \pm SEM, treated over control (=Krebs-Ringer-HEPES buffer) set to $\%$. $n=2-3 \mathrm{tr}=2-4$; one-way ANOVA vs. control followed by a Holm-Sidak post hoc test $(* *: p<0.01)$. 


\subsubsection{Proton Secretion}

After a $10 \mathrm{~min}$ incubation time with $0.1 \mu \mathrm{M}$ serotonin, HGT-1 cells showed a reduced proton secretion in comparison to the untreated control analyzed by means of intracellular proton index (IPX) $(0.21 \pm 0.03$ vs. control $-0.00 \pm 0.02)$ (Figure 6A). Tested serotonin and L-Arg concentrations are based on physiologically relevant concentrations [41-43]. Incubation with $10 \mu \mathrm{M}$ of the $5-\mathrm{HT} 3$ receptor antagonist granisetron reduced the L-Arginduced proton secretion from IPX $-3.48 \pm 0.13$ to $-3.00 \pm 0.53(p<0.05$, Figure $6 \mathrm{~B})$, while incubation with SERT inhibitor fluoxetine showed no impact (Figure S6).
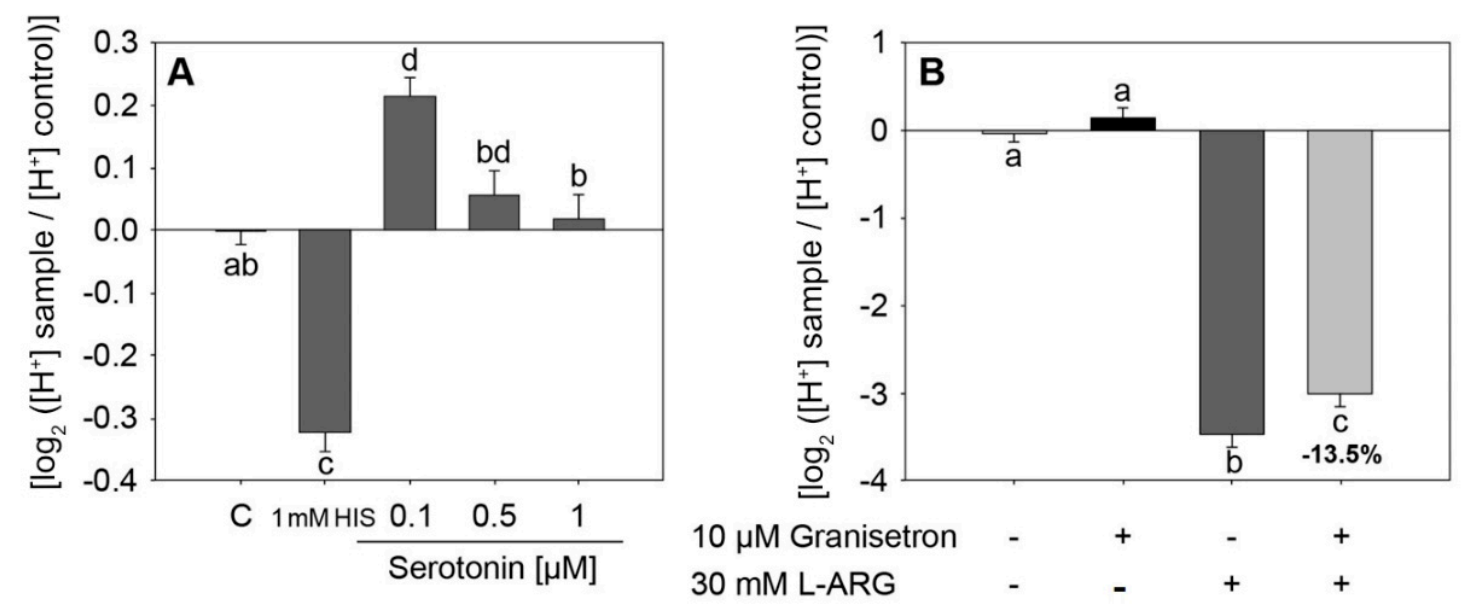

Figure 6. (A) Impact of incubation with $0.1-1 \mu \mathrm{M}$ serotonin on proton secretion in HGT-1 cells. 1 mM HIS represents the positive control histamine in a concentration of $1 \mathrm{mM} . n=3-6, \operatorname{tr}=6$; statistics: one-way ANOVA on ranks followed by Dunn's post hoc test vs. control. (B) Impact of $10 \mu \mathrm{M}$ 5-HT3 receptor antagonist granisetron on L-Arg-induced proton secretion, $n=3$, $\operatorname{tr}=3-6$; statistics: one-way ANOVA followed by Holm-Sidak post hoc test. Different letters indicating statistical differences $(p<0.05)$.

\section{Discussion}

The indole amine serotonin has been described to exert a wide variety of actions in the human body in health and disease, reaching from its role in gastrointestinal function and the regulation of nausea, vomiting [44] and food intake [2,5] to several brain disorders, such as schizophrenia [1]. Several cell lines have been shown to release serotonin upon stimulation [25], among which enterochromaffin QGP-1 cells [26,29] and enterocyte-like Caco-2 cells $[28,29]$ represent cell models of peripheral serotonin release. As several reports indicate the presence of serotonin in the stomach, we investigated the capacity of a cell line originating from an adenocarcinoma of the stomach and human antrum specimen to synthesize and consequently release serotonin upon stimulation by L-Arg, an amino acid for which satiating effects have been demonstrated [11]. Moreover, a functional role of serotonin on mechanisms regulating gastric acid secretion was elucidated.

First, we analyzed the expression of enzymes involved in the biosynthesis of serotonin. Similar to the study by Vieira-Coe et al. [27], reporting the ability of Caco-2 cells to synthesize and degrade serotonin, we determined the activity of AADC based on their method. In this experiment, we showed an increase in the serotonin concentration with increasing substrate concentrations of 5-HTP, thereby indicating the presence of functional AADC. Taken together, the presence of functional AADC suggests that HGT-1 cells are capable of synthesizing serotonin. To show that serotonin is, in fact, present in HGT-1 cells, we performed immunostaining experiments. Furthermore, human adenocarcinoma excised from the proximal stomach showed scattered single-cell staining positive for serotonin. This pattern is similar to the expression pattern of serotonin cells in healthy stomach tissue, in which only a low number of serotonin-expressing cells was found compared to other cell types present [19]. This finding is also concordant with the literature, demonstrating only a low number of scattered carcinoma cells with serotonin expression. In addition, 
only a very low percentage of serotonin expression in gastric adenocarcinomas has been described [45]. Regardless of the number of cells staining positive, this suggests that serotonin is present in proximal stomach samples of both healthy and diseased donors. Next, we compared the serotonin content of HGT-1 cells to cell lines, which have been described to release serotonin upon stimulation in previous studies. In the cellular supernatants of the enterochromaffin cell line QGP-1 and differentiated Caco- 2 cells, serving as a cell model of enterocytes, we detected lower serotonin quantities than in the supernatant collected from HGT-1 cells. L-Tryptophan (L-Trp) has to be present in the cells in order to serve as substrate for serotonin synthesis. As the actual L-Trp level in the supernatant collected from HGT-1 cells was unknown, we analyzed L-Trp, 5-HTP and 5-HT by LC-MS /MS to exclude the Trp level in the sample exceeding the level reported to cross-react by the ELISA manufacturer. This showed L-Trp to be present, but not in concentrations high enough to interfere with the ELISA. Interestingly, we detected both L-Trp and serotonin, but not 5-HTP. This fits with the conversion of L-Trp to 5-HTP being the rate-limiting step, and, hence, 5-HTP being converted to serotonin immediately.

In addition to showing the enzymes required in the biosynthesis of serotonin on a functional level, we assessed the mRNA expression of the cultured cells, including several serotonin receptors and the serotonin reuptake receptor gene SLC6A4 by qPCR. This demonstrated TPH1, TPH2, SLC6A4, HTR3C/D and HTR7 to be expressed. However, we failed to quantify the gene expression of the second enzyme required in the synthesis of serotonin, AADC. As we were able to show AADC activity, and AADC is a prerequisite in the biosynthesis of serotonin, it seems likely that the AADC mRNA level was below the limit of detection of our qPCR method. In addition, mRNA expression of the receptor subtypes HTR1A, HTR2A, and HTR3A was below the limit of detection. However, genes encoding for serotonin receptors have been described in stomach tissue previously. A study by Van Lelyveld [46] reported very low gene expression levels of HTR $3 A$ and HTR3B in the stomach. Furthermore, the authors showed expression of HTR3C, HTR3E and HTR4 in both antrum and fundus of healthy donor samples [46]. Among the currently known seven serotonin receptor families, 5-HT3 receptors are the only ones belonging to the family of cysloop ligand-gated ion channel [44]. Serotonin has been suggested to modulate the secretion of gastric acid via this subtype of serotonin receptors [22]. Furthermore, a link between intragastric $\mathrm{pH}$ and serotonin release has been shown using perfused rat stomach [47]. In this study, at an intragastric $\mathrm{pH}$ of 2 , the basal serotonin release into the vasculature was reported to be 10 times higher than that into the gastric lumen [47]. This may be of particular interest in HGT-1 cells, as they have previously been used to study the influence of a number of compounds on proton secretion $[34,48]$. Hence, we tested the effect of serotonin on proton secretion from HGT-1 cells, showing incubation with $0.1 \mu \mathrm{M}$ serotonin to significantly reduce proton secretion, thus suggesting that serotonergic pathways may influence proton secretion in this cell line, similarly, as suggested by Lai et al. [22]. The fact that a lower concentration of $100 \mathrm{nM}$ serotonin decreased proton secretion, whereas higher concentrations of 500 and $1000 \mathrm{nM}$ serotonin had no effect might be explained by a hormetic response [49]. The 5-HT3 receptors are also of interest in the context of gastric emptying. An in vivo study on male Wistar rats carried out by Doihara et al. [26] reported a delay in gastric emptying by TRPA1 agonists involving a serotonergic pathway. In this study, a delay in gastric emptying was observed after administration of $1 \mathrm{mg} \times \mathrm{kg}^{-1}$ serotonin. The effect of TRPA1 agonists on gastric emptying was abolished in experiments using either the TPH inhibitor PCPA or the 5-HT3 receptor inhibitor granisetron.

Next, we tested the effect of L-Arg on serotonin release from HGT- 1 cells and ex vivo samples derived from human antrum specimen. This showed, in both the ex vivo and in vitro setting, treatment with L-Arg to increase the serotonin content in the cellular supernatant collected. Although serotonin release by human antrum samples was reduced after exposure to high L-Arg concentrations of $50 \mathrm{mM}$, a lower concentration of $10 \mathrm{mM}$ $\mathrm{L}$-Arg increased serotonin release. Here, we hypothesize a hormetic dose-response of L-Ag on serotonin release. The increase could either be due to a rise in serotonin release or due 
to an impact on the serotonin transporter SERT. SERT expression has been reported in the stomach [50] and was also detected by qPCR in HGT-1 cells in our study. Our microarray experiment revealed treatment with L-Arg to have a strong impact on gene expression of HGT 1 cells. Pathway analysis with the free online tool DAVID showed the cluster with the second highest enrichment score to consist predominantly of genes involved in serotonin release. As a result, we carried out $\mathrm{qPCR}$ experiments, showing L-Arg to alter the gene expression of HTR3C, HTR7, SLC6A4, and TPH2. As L-Arg influenced the expression of HTR3 and the HTR3C subunit has previously been described in the modulation of gastric acid secretion [22], we carried experiments into a possible link between L-Arg-induced serotonin release and the 5-HT3 receptor by performing co-incubation experiments with the 5-HT3 receptor antagonist granisetron. The increase in extra-cellular serotonin after treatment with L-Arg was prevented by co-incubation with granisetron, indicating that a 5-HT3 receptor-mediated pathway may be involved. A similar control of serotonin release by 5 -HT3 autoreceptors has been shown for enterochromaffin cells from isolated intestinal segments of guinea pigs [51]. Moreover, a study showing delayed gastric emptying after serotonin administration revealed this effect to be abolished by either inhibiting the 5HT3 receptor or TPH as well [26]. In the present study, the effect of L-Arg on proton secretion was decreased by granisetron co-incubation, pointing to an involvement of 5-HT3 receptors not only in the regulation of serotonin release, but also of the proton secretion in HGT-1 cells.

Whether the results obtained from HGT-1 cells point to a possible regulation in vivo or not will need to be addressed in either human intervention studies or animal trials. In addition, the mechanism linking gastric acid secretion and serotonin release may be analyzed further in HTR3 knock-out models, and by identifying cellular mediators involved such as $\mathrm{Ca}^{2+}$ mobilization, cAMP or ERK activation.

In conclusion, this study shows serotonin synthesis and release from HGT-1 cells as a model system for peripheral serotonin in the stomach and human antrum specimen. Furthermore, experiments using the 5-HT3 receptor antagonist granisetron suggest that this serotonin autoreceptor is involved in both proton and serotonin secretion. Overall, our data suggest a feedback mechanism by which serotonin release, known for its impact on food intake [9-12], not only reduces gastric activity upon food-stimulation, but also might contribute to satiation. To elucidate the satiating impact serotonin may have after release from endocrine cells of the stomach, animal trials and human intervention studies need to be conducted.

\section{Materials and Methods}

\subsection{Materials}

All reagents were obtained from Sigma-Aldrich (Vienna, Austria) unless stated otherwise. Anti-5HT and Anti-TPH2 antibodies were purchased from Merck-Millipore (Vienna, Austria).

\subsection{Cell Culture}

The human gastric tumor cell line (HGT-1, Dr. C. Laboisse, Nantes, France) was cultivated using Dulbecco's modified Eagle medium (DMEM) containing $4.5 \mathrm{~g} \mathrm{~L}^{-1}$ glucose. The medium was supplemented with $4 \mathrm{mM}$ L-glutamine, 10\% fetal bovine serum and 1\% penicillin/streptomycin (100 units penicillin, $171 \mu \mathrm{M}$ streptomycin). Cells were maintained in a humidified incubator at $5 \% \mathrm{CO}_{2}$ and sub-cultured at $90 \%$ confluence, using cells between passage 60 and 80 in experiments. Caco- 2 cells were obtained from American Type Culture Collection (ATCC, Manassas, VA, USA) and maintained in DMEM containing $4.5 \mathrm{~g} \mathrm{~L}^{-1}$ glucose, $10 \%$ fetal bovine serum and 1\% penicillin/streptomycin. QGP-1 cells were cultivated in RPMI medium supplemented with 10\% fetal bovine serum and 1\% penicillin/streptomycin. 


\subsection{Cell Viability Assay}

HGT- 1 cells were seeded in 96-well plates at a density of $1 \times 105$ cells per well and left to settle for $24 \mathrm{~h}$. Next, the cells were incubated with Krebs-Ringer-HEPES buffer (KRHB, (10 mM HEPES, $11.7 \mathrm{mM}$ Glucose, $4.7 \mathrm{mM} \mathrm{KCl}, 130 \mathrm{mM} \mathrm{NaCl}, 1.3 \mathrm{mM} \mathrm{CaCl}_{2}, 1.2 \mathrm{mM}$ $\mathrm{Mg}_{2} \mathrm{SO}_{4}, 1.2 \mathrm{mM} \mathrm{KH}_{2} \mathrm{PO}_{4}$ ), supplemented with $0.1 \%$ ascorbic acid, $\mathrm{pH} 7.4$ ) or serum-free DMEM for $5 \mathrm{~min}$. Then the incubation solution was replaced with MTT working solution (3-(4,5-dimethylthiazolyl-2)-2,5-diphenyltetrazolium bromide, $100 \mu \mathrm{L}, 1 \mathrm{mg} \mathrm{mL}^{-1}$ ) and incubated for $15 \mathrm{~min}$ at $37^{\circ} \mathrm{C}$ in a humidified incubator. Finally, the MTT working solution was removed, $150 \mu \mathrm{L}$ DMSO was added, and the absorbance was read at $570 \mathrm{~nm}$.

\subsection{RNA Isolation and $q P C R$}

HGT-1 cells were seeded in 24-well plates at a density of $1.5 \times 10^{5}$ cells per well. The cells were treated with L-Arg for $3 \mathrm{~h}$ and subsequently washed with ice cold PBS. Further, RNA was isolated using the PeqLab total RNA kit (Peqlab, VWR, Vienna, Austria), following the manufacturer's protocol. RNA quality and concentration were analyzed by the A260/280 absorbance ratio using the nanoquant plate for the Tecan Infinite 200 PRO Plate Reader. The purity of all samples was ensured within a ratio between 1.8 and 2.0. Then, $1 \mu \mathrm{g}$ of the isolated RNA was reversely transcribed with the high-capacity cDNA kit (Applied Biosystems, Thermo Fisher Scientific, Vienna, Austria) The synthesized cDNA was added to a qPCR mix containing fast SYBR green master mix (Applied Biosystems, Thermo Fisher Scientific, Waltham, MA, USA) and the amplification assessed on a StepOnePlus device (Applied Biosystems, Thermo Fisher Scientific, Waltham, MA, USA). The qPCR cycles started with an initial denaturation step at $95^{\circ} \mathrm{C}$ for $20 \mathrm{~s}$, followed by 40 amplification cycles implying of denaturation at $95^{\circ} \mathrm{C}$ for $3 \mathrm{~s}$, annealing at $60^{\circ} \mathrm{C}$ for $30 \mathrm{~s}$, and elongation with a fluorescence measurement at $67^{\circ} \mathrm{C}$ for $15 \mathrm{~s}$. TATA-box binding protein (TBP), glyceraldehyde 3-phosphate dehydrogenase (GADPH) and peptidylprolyl isomerise A (PPIA) were used as endogenous controls. The sequences of all primers are provided in Table S1. Primers were either designed using PrimerBlast or taken from PrimerBank. LinReg v2013.0. [52] was used in the data analysis.

\subsection{DNA Microarrays}

Microarray analysis was carried out as described previously [53], using a reaction chamber allowing for the simultaneous synthesis of two microarrays [53]. HGT-1 cells were seeded in 6-well plates and left to settle for $24 \mathrm{~h}$. Thereafter, cells were incubated with $50 \mathrm{mM}$ L-Arg for $3 \mathrm{~h}$ prior to RNA isolation (RNeasy Mini Kit, Qiagen, Hilden, Germany). Microarray labelling, hybridization and analysis were carried out as described previously [25], however an Axon GenePix 4400A was used for scanning the microarrays.

\subsection{Aromatic Amino Acid Decarboxylase (AADC) Activity}

The method used in the assessment of the enzymatic activity of the aromatic amino acid decarboxylase was modified from Vieira-Coelho et al. [27]. Briefly, HGT-1 cells grown to confluence in a T175 flask were washed with HBSS and detached from the flask by scraping, after the addition of $1 \mathrm{~mL}$ HBSS. The cells were then subjected to three freezethaw cycles in liquid nitrogen, homogenized using a Potter-Elvehjem device, passed through a small-bore needle, and centrifuged at $4{ }^{\circ} \mathrm{C}$ (full speed, $15 \mathrm{~min}$ ). A total of $100 \mu \mathrm{L}$ of the supernatant was added to incubation medium $(100 \mu \mathrm{L})$ and incubated for $15 \mathrm{~min}$ at room temperature. The incubation medium consisted of: tolcapone $(4 \mu \mathrm{M})$, paragyline $(300 \mu \mathrm{M})$, pyridoxal phosphate $(240 \mu \mathrm{M})$, sodium borate $(110 \mu \mathrm{M}), \mathrm{Na}_{2} \mathrm{HPO}_{4}(150 \mu \mathrm{M})$, $\mathrm{KH}_{2} \mathrm{PO}_{4}(350 \mu \mathrm{M})$ and HBSS. Next, $200 \mu \mathrm{L}$ 5-HTP $(0-9 \mathrm{mM})$ and ascorbic acid, giving a final concentration of $0.1 \%$, were added. After 15 min incubation in the dark, $60 \mu \mathrm{L} 6 \mathrm{M}$ hydrochloric acid were added and centrifuged at $4{ }^{\circ} \mathrm{C}$ for $15 \mathrm{~min}$. The supernatant was passed through a $0.2 \mu \mathrm{m}$ filter prior to injecting $50 \mu \mathrm{L}$ into the HPLC column. The analytical method used is described in the LC-MS/MS section of the supplementary materials. The total protein content of the cell lysate was determined by Bradford assay. 


\subsection{Serotonin Staining}

Histological specimens were obtained from two patients from the PathologischBakteriologisches Institut, Klinikum Donaustadt, Vienna, Austria after signing a written informed consent that covers all diagnostic procedures on the extracted tissue. One specimen was derived from a 79-year old female patient undergoing distal partial gastrectomy for benign peptic ulcer with perforation. The other specimen was derived from a 47 -year old male patient with proximal high-grade adenocarcinoma. Immunohistochemistry was performed on $5 \mu \mathrm{m}$-thick formalin-fixed, paraffin-embedded whole tissue sections. Slides were processed in the fully automated staining instrument Benchmark ULTRA using ultraView Universal DAB Detection Kit (Ventana Medical Systems, Oro Valley, AZ, USA). The primary antibody M0758 (clone 5HT-H209, Agilent DAKO, Santa Clara, CA, USA) was applied at $1: 5$ for $32 \mathrm{~min}$ at $37^{\circ} \mathrm{C}$. No pretreatment was performed. All counterstaining was performed with hematoxylin. Blocking experiments in order to control for unspecific staining were performed using normal mouse IgG1 serum replacing the primary antibody. HGT-1 cells were adhered on object slides and treated in a similar way.

\subsection{Serotonin Release}

\subsubsection{Serotonin ELISA}

Analysis of serotonin release in cell supernatants was carried out using High Sensitive Serotonin ELISA (DLD Diagnostika, Hamburg, Germany) as described previously [28]. HGT-1 cells were seeded in 24-well plates at a density of $1.5 \times 10^{5}$ cells per well. One day after seeding, the cells were washed with pre-warmed PBS and subsequently incubated with either $200 \mu \mathrm{L}$ KRHB (10 mM HEPES, $11.7 \mathrm{mM}$ glucose, $4.7 \mathrm{mM} \mathrm{KCl}, 130 \mathrm{mM} \mathrm{NaCl}$, $1.3 \mathrm{mM} \mathrm{CaCl}_{2}, 1.2 \mathrm{mM} \mathrm{Mg}_{2} \mathrm{SO}_{4}, 1.2 \mathrm{mM} \mathrm{KH}_{2} \mathrm{PO}_{4}$, supplemented with $0.1 \%$ ascorbic acid, $\mathrm{pH}$ 7.4) or $200 \mu \mathrm{L} \mathrm{KRHB}$ with $30 \mathrm{mM} \mathrm{L}$-Arg for $5 \mathrm{~min}$ in a humidified incubator at $37^{\circ} \mathrm{C}$ in the dark. To assess whether 5-HT3 receptors are involved, co-incubations with $10 \mu \mathrm{M}$ 5-HT3 antagonist granisetron were carried out. After incubation, the supernatant was collected, diluted 1:5 with KRHB and the serotonin concentration assessed. A more detailed procedure for each cell type is given in the supplemental information.

\subsubsection{Serotonin Release from Human Antrum Samples}

The effect of L-Arg on serotonin release in HGT-1 cell line was assessed in human gastric tissue. Explant culture protocol was conducted as described before [54]. Anonymized antrum samples were derived from gastric sleeve surgery patients after written consent and put in ice cold Krebs-Ringer-HEPES buffer immediately. Antrum slices were thoroughly washed with Krebs-Ringer-HEPES buffer, cut and weighed. Gastric tissue was placed in 6-well dishes containing $3 \mathrm{~mL}$ DMEM $+10 \%$ FBS $200 \mathrm{mM} \mathrm{L}$-glutamine and 1\% P/S and incubated for $1 \mathrm{~h}$ in an incubator at $37^{\circ} \mathrm{C}$ and $5 \% \mathrm{CO}_{2}$. Afterwards, samples were carefully washed with prewarmed PBS and transferred to a new 6-well dish containing $1 \mathrm{~mL}$ of 10 , $30,50 \mathrm{mM}$ of L-Arg or Krebs-Ringer-HEPES buffer, supplemented with $0.1 \%$ ascorbic acid, $\mathrm{pH} 7.4$ and incubated for $5 \mathrm{~min}$. Finally, the supernatant was centrifuged two times for 1 min at $7000 \times g$ at $4{ }^{\circ} \mathrm{C}$ and stored at $-80^{\circ} \mathrm{C}$ until measurement. Serotonin release was assessed using a serotonin ELISA as described above.

\subsection{Proton Secretory Activity}

Proton secretory activity and corresponding data analysis were conducted by means of the $\mathrm{pH}$-sensitive fluorescence dye 1,5 carboxy-seminaphto-rhodafluor acetoxymethylester (SNARF-1-AM; Life Technologies), as described previously [34,35,39]. Briefly, HGT-1 cells were seeded $24 \mathrm{~h}$ prior the experiment, in 96-well plates in a density of 100,000 cells/well. For incubation, cells were washed with KRPH and incubated with $3 \mu \mathrm{M}$ SNARF dye for $30 \mathrm{~min}\left(37^{\circ} \mathrm{C}, 5 \% \mathrm{CO}_{2}\right)$. Subsequently, cells were washed again and treated with 0.1-10 $\mu \mathrm{M}$ serotonin, $30 \mathrm{mM}$ L-Arg. Furthermore, co-incubation experiments with 5HT3 receptor inhibitor granisetron $(10 \mu \mathrm{M})$ or SERT inhibitor fluoxetine were carried out. $1 \mathrm{mM}$ histamine was tested as a positive control. The intracellular proton index (IPX) was 
calculated as the $\log 2$ data of the ratio between treated and untreated control (KRHP) cells. IPX values indicate the proton secretory of the cells, whereby lower IPX values demonstrate an increased proton secretion.

\subsection{LC-MS/MS}

Briefly, tryptophan, 5-hydroxytryptophan and serotonin in the cellular supernatants collected were analyzed in a single run by LC-MS/MS in positive MRM mode. The detailed method is described in the supplemental information.

\subsection{Statistical Analysis}

SigmaPlot 11 was used for statistical analysis. Data are presented as average \pm SEM or standard deviation, as outlined in the corresponding figure legend. Similarly, the numbers of biological replicates and the statistic tests performed are stated in the legend of the corresponding figure or table. Treatments are shown in relation to control cells set to 1 or $100 \%$, labelled as treated over control in the figures. Image J was used for reading out the fluorescence of single cells. Proton secretion data were subjected to Nalimov's outlier test prior to analysis. Detailed information on the statistical tests applied is given in the individual table/figure caption.

\section{Conclusions}

In conclusion, this study shows serotonin synthesis and release from HGT-1 cells as a model system for peripheral serotonin in the stomach and human antrum specimen. Furthermore, experiments using the 5-HT3 receptor antagonist granisetron suggest this serotonin autoreceptor to be involved in both proton and serotonin secretion. Overall, our data suggest a feedback mechanism by which serotonin release, known for its regulation of food intake, not only reduces gastric activity upon food-stimulation, but, further, might contribute to short term satiety regulation. To elucidate the satiating impact serotonin may have after release from endocrine cells of the stomach, animal trials and human intervention studies need to be conducted.

Supplementary Materials: The following are available online at https:/ /www.mdpi.com/article/ 10.3390/ijms22115881/s1, Table S1: Sequence and product size of the primers used for qPCR experiments, Table S2: MRM settings for the simultaneous detection of L-Trp, 5-HTP and serotonin by LC-MS/MS, Figure S1: Results of the cell viability assay by means of MTT assay, Figure S2: Pg/ serotonin cell $n=3-4$ with 2 technical replicates each, Figure S3: Immunofluorescence of HGT-1 cells, Figure S4: Scatter plot of $\log 2$ transformed intensities of control and treatment with L-Arg for $3 \mathrm{~h}$, Figure S5: Typical LC-MS/MS chromatogram of the cellular supernatant collected from HGT-1 cells, Figure S6: Impact of SERT inhibitor fluoxetine on L-Arg induced proton secretion.

Author Contributions: A.-K.H., B.L., A.R. and V.S. (Veronika Somoza) designed research; A.-K.H., K.S., V.S. (Verena Stoeger), B.L., M.Z., M.M.S., J.K.H., A.R., S.K., N.K. performed research; A.-K.H., K.S., V.S. (Verena Stoeger), B.L., M.Z., M.P., J.K.H., A.R., M.M.S. and V.S. (Veronika Somoza) analyzed data; and A.-K.H., B.L., K.S. and V.S. (Veronika Somoza) wrote the manuscript. All authors have read and agreed to the published version of the manuscript.

Funding: Financial support was provided by the Austrian Federal Ministry of Economy, Family and Youth, the Austrian National Foundation for Research, Technology and Development, and the Austrian Science Fund (grant FWF P23797). The authors thank for the financial support by Symrise AG and Christian Doppler Gesellschaft.

Institutional Review Board Statement: Ethical review and approval were waived for this study, due to the Regulations of the University of Vienna (Paragraph 2.1, http:/ / satzung.univie.ac.at/ ethikkommission-der-universitaet-wien/, accessed on 26 May 2019). Specifically, approval of the ethics committee was not required as: (1) the study did not affect the physical or psychological integrity of the participants; (2) no personal information regarding the volunteer's identity was collected; and (3) the study was not in any way counter to the interests of the participants. According to these guidelines, the study is not considered a "Research Project on or with Humans" since it 
involved anonymized gastric samples collected from healthy individuals during bariatric surgery. Informed consent was obtained from all subjects who agreed to the subsequent study protocol, namely that parts of their excised stomach tissue would be anonymized and analyzed for ex vivo serotonin secretion.

Informed Consent Statement: Informed consent was obtained from all subjects involved in the study.

Data Availability Statement: The data that support the findings of this study are available from the corresponding author, upon reasonable request.

Acknowledgments: The authors gratefully acknowledge C. L. Laboisse (Inserm 94-04, Facultè de Medicine, Nantes) for providing the HGT-1 cells, clone6.

Conflicts of Interest: The authors declare no conflict of interest.

\section{References}

1. Sumiyoshi, T.; Kunugi, H.; Nakagome, K. Serotonin and dopamine receptors in motivational and cognitive disturbances of schizophrenia. Front. Neurosci. 2014, 8, 395. [CrossRef]

2. Andrews, P.W.; Bharwani, A.; Lee, K.R.; Fox, M.; Thomson, J.A., Jr. Is serotonin an upper or a downer? The evolution of the serotonergic system and its role in depression and the antidepressant response. Neurosci. Biobehav. Rev. 2015, 51, 164-188. [CrossRef]

3. Bowman, M.A.; Vitela, M.; Clarke, K.M.; Koek, W.; Daws, L.C. Serotonin transporter and plasma membrane monoamine transporter are necessary for the antidepressant-like effects of ketamine in mice. Int. J. Mol. Sci. 2020, 21, 7581. [CrossRef]

4. Srivastava, A.; Singh, P.; Gupta, H.; Kaur, H.; Kanojia, N.; Guin, D.; Sood, M.; Chadda, R.K.; Yadav, J.; Vohora, D.; et al. Systems approach to identify common genes and pathways associated with response to selective serotonin reuptake inhibitors and major depression risk. Int. J. Mol. Sci. 2019, 20, 1993. [CrossRef]

5. Halford, J.C.; Harrold, J.A.; Lawton, C.L.; Blundell, J.E. Serotonin (5-HT) drugs: Effects on appetite expression and use for the treatment of obesity. Curr. Drug Targets 2005, 6, 201-213. [CrossRef] [PubMed]

6. Hess, R.; Cross, L.B. The safety and efficacy of lorcaserin in the management of obesity. Postgrad. Med. 2013, 125, 62-72. [CrossRef]

7. Yuen, H.; Hung, A.; Yang, A.W.H.; Lenon, G.B. Mechanisms of action of cassiae semen for weight management: A computational molecular docking study of serotonin receptor 5-HT2C. Int. J. Mol. Sci. 2020, 21, 1326. [CrossRef]

8. Pollock, J.D.; Rowland, N. Peripherally administered serotonin decreases food intake in rats. Pharmacol. Biochem. Behav. 1981, 15, 179-183. [CrossRef]

9. Hochkogler, C.; Lieder, B.; Rust, P.; Berry, D.; Meier-Menches, S.; Pignitter, M.; Riva, A.; Leitinger, A.; Bruk, A.; Wagner, S.; et al. A 12-week intervention with nonivamide, a TRPV1 agonist, prevents a dietary-induced body fat gain and increases peripheral serotonin in moderately overweight subjects. Mol. Nutr. Food Res. 2016, 61, 1600731. [CrossRef] [PubMed]

10. Hochkogler, C.; Liszt, K.; Lieder, B.; Stöger, V.; Stübler, A.; Pignitter, M.; Hans, J.; Widder, S.; Ley, J.; Krammer, G.; et al. Appetite-inducing effects of homoeriodictyol: Two randomized, cross-over interventions. Mol. Nutr. Food Res. 2017, 61, 1700459. [CrossRef]

11. Stoeger, V.; Lieder, B.; Riedel, J.; Schweiger, K.; Hoi, J.; Ruzsanyi, V.; Klieber, M.; Rust, P.; Hans, J.; Ley, J.P.; et al. Wheat protein hydrolysate fortified with l-arginine enhances satiation induced by the capsaicinoid nonivamide in moderately overweight male subjects. Mol. Nutr. Food Res. 2019, 63, e1900133. [CrossRef]

12. Schweiger, K.; Grüneis, V.; Treml, J.; Galassi, C.; Karl, C.M.; Ley, J.P.; Krammer, G.E.; Lieder, B.; Somoza, V. Sweet taste antagonist lactisole administered in combination with sucrose, but not glucose, increases energy intake and decreases peripheral serotonin in male subjects. Nutrients 2020, 12, 3133. [CrossRef] [PubMed]

13. Gershon, M.D.; Tack, J. The serotonin signaling system: From basic understanding to drug development for functional GI disorders. Gastroenterology 2007, 132, 397-414. [CrossRef]

14. Mawe, G.M.; Hoffman, J.M. Serotonin signalling in the gut-functions, dysfunctions and therapeutic targets. Nat. Rev. Gastroenterol. Hepatol. 2013, 10, 473-486. [CrossRef] [PubMed]

15. Ponti, F.D. Pharmacology of serotonin: What a clinician should know. Gut 2004, 53, 1520. [CrossRef] [PubMed]

16. Sikander, A.; Rana, S.V.; Prasad, K.K. Role of serotonin in gastrointestinal motility and irritable bowel syndrome. Clin. Chim. Acta 2009, 403, 47-55. [CrossRef]

17. Nakatani, Y.; Sato-Suzuki, I.; Tsujino, N.; Nakasato, A.; Seki, Y.; Fumoto, M.; Arita, H. Augmented brain 5-HT crosses the blood-brain barrier through the 5-HT transporter in rat. Eur. J. Neurosci. 2008, 27, 2466-2472. [CrossRef]

18. Mazda, T.; Yamamoto, H.; Fujimura, M.; Fujimiya, M. Gastric distension-induced release of 5-HT stimulates c-fos expression in specific brain nuclei via 5-HT3 receptors in conscious rats. Am. J. Physiol. Gastr. Liver Physiol. 2004, 287, G228-G235. [CrossRef]

19. Choi, E.; Roland, J.T.; Barlow, B.J.; O’Neal, R.; Rich, A.E.; Nam, K.T.; Shi, C.; Goldenring, J.R. Cell lineage distribution atlas of the human stomach reveals heterogeneous gland populations in the gastric antrum. Gut 2014, 63, 1711-1720. [CrossRef]

20. Kellum, J.M., Jr.; Jaffe, B.M. Release of immunoreactive serotonin following acid perfusion of the duodenum. Ann. Surg. 1976, 184, 633-636. [CrossRef] 
21. LePard, K.J.; Stephens, R.L., Jr. Serotonin inhibits gastric acid secretion through a 5-hydroxytryptamine1-like receptor in the rat. J. Pharmacol. Exp. Ther. 1994, 270, 1139-1144.

22. Lai, Y.C.; Ho, Y.; Huang, K.H.; Tsai, L.H. Effects of serotonin on acid secretion in isolated rat stomach: The role of 5-HT3 receptors. Chin. J. Physiol. 2009, 52, 395-405. [CrossRef]

23. Bado, A.; Lewin, M.J.; Dubrasquet, M. Effects of bombesin on food intake and gastric acid secretion in cats. Am. J. Physiol. 1989, 256, R181-R186. [CrossRef]

24. Lieverse, R.J.; Jansen, J.B.; Van de Zwan, A.; Samson, L.; Masclee, A.A.; Rovati, L.C.; Lamers, C.B. Bombesin reduces food intake in lean man by a cholecystokinin-independent mechanism. J. Clin. Endocrinol. Metab. 1993, 76, 1495-1498. [CrossRef]

25. Rohm, B.; Holik, A.K.; Somoza, M.M.; Pignitter, M.; Zaunschirm, M.; Ley, J.P.; Krammer, G.E.; Somoza, V. Nonivamide, a capsaicin analog, increases dopamine and serotonin release in SH-SY5Y cells via a TRPV1-independent pathway. Mol. Nutr. Food Res. 2013, 57, 2008-2018. [CrossRef] [PubMed]

26. Doihara, H.; Nozawa, K.; Kawabata-Shoda, E.; Kojima, R.; Yokoyama, T.; Ito, H. TRPA1 agonists delay gastric emptying in rats through serotonergic pathways. Naunyn-Schmiedeberg's Arch Pharmacol. 2009, 380, 353-357. [CrossRef] [PubMed]

27. Vieira-Coelho, M.A.; Teixeira, V.L.; Guimarães, J.T.; Serrão, M.P.; Soares-da-Silva, P. Caco-2 cells in culture synthesize and degrade dopamine and 5-hydroxytryptamine: A comparison with rat jejunal epithelial cells. Life Sci. 1999, 64, 69-81. [CrossRef]

28. Lieder, B.; Hoi, J.K.; Holik, A.K.; Geissler, K.; Hans, J.; Friedl, B.; Liszt, K.; Krammer, G.E.; Ley, J.P.; Somoza, V. The flavanone homoeriodictyol increases SGLT-1-mediated glucose uptake but decreases serotonin release in differentiated Caco-2 cells. PLoS ONE 2017, 12, e0171580. [CrossRef] [PubMed]

29. Lieder, B.; Hoi, J.; Burian, N.; Hans, J.; Holik, A.; Marquez, L.B.; Ley, J.; Hatt, H.; Somoza, V. Structure-dependent effects of cinnamaldehyde derivatives on TRPA1-induced serotonin release in human intestinal cell models. J. Agric. Food Chem. 2020, 68, 3924-3932. [CrossRef] [PubMed]

30. Laboisse, C.L.; Augeron, C.; Couturier-Turpin, M.H.; Gespach, C.; Cheret, A.M.; Potet, F. Characterization of a newly established human gastric cancer cell line HGT-1 bearing histamine $\mathrm{H}_{2}$-receptors. Cancer Res. 1982, 42, 1541-1548.

31. Sandle, G.I.; Fraser, G.; Fogg, K.; Warhurst, G. Properties of a potassium channel in cultured human gastric cells (HGT-1) possessing specific omeprazole binding sites. Gut 1993, 34, 1331-1338. [CrossRef] [PubMed]

32. Nonotte, I.; Laliberte, M.F.; Remy-Heintz, N.; Laliberte, F.; Chevillard, C. Expression of angiotensin I-converting enzyme in the human gastric HGT-1 cell line. Regul. Pept. 1995, 59, 379-387. [CrossRef]

33. Carmosino, M.; Procino, G.; Casavola, V.; Svelto, M.; Valenti, G. The cultured human gastric cells HGT-1 express the principal transporters involved in acid secretion. Pflug. Arch. 2000, 440, 871-880. [CrossRef] [PubMed]

34. Weiss, C.; Rubach, M.; Lang, R.; Seebach, E.; Blumberg, S.; Frank, O.; Hofmann, T.; Somoza, V. Measurement of the intracellular ph in human stomach cells: A novel approach to evaluate the gastric acid secretory potential of coffee beverages. J. Agric. Food Chem. 2010, 58, 1976-1985. [CrossRef]

35. Liszt, K.I.; Ley, J.P.; Lieder, B.; Behrens, M.; Stöger, V.; Reiner, A.; Hochkogler, C.M.; Köck, E.; Marchiori, A.; Hans, J.; et al. Caffeine induces gastric acid secretion via bitter taste signaling in gastric parietal cells. Proc. Natl. Acad. Sci. USA 2017, 114, E6260-E6269. [CrossRef]

36. Alamshah, A.; McGavigan, A.K.; Spreckley, E.; Kinsey-Jones, J.S.; Amin, A.; Tough, I.R.; O’Hara, H.C.; Moolla, A.; Banks, K.; France, R.; et al. L-arginine promotes gut hormone release and reduces food intake in rodents. Diabetes Obes. Metab. 2016, 18, 508-518. [CrossRef]

37. Uchida, M.; Kobayashi, O.; Saito, C. Correlation between gastric emptying and gastric adaptive relaxation influenced by amino acids. J. Neurogastroenterol. Motil. 2017, 23, 400-408. [CrossRef]

38. Sanger, G.J.; Nelson, D.R. Selective and functional 5-hydroxytryptamine3 receptor antagonism by BRL 43694 (granisetron). Eur. J. Pharmacol. 1989, 159, 113-124. [CrossRef]

39. Stoeger, V.; Liszt, K.I.; Lieder, B.; Wendelin, M.; Zopun, M.; Hans, J.; Ley, J.P.; Krammer, G.E.; Somoza, V. Identification of bitter-taste intensity and molecular weight as amino acid determinants for the stimulating mechanisms of gastric acid secretion in human parietal cells in culture. J. Agric. Food Chem. 2018, 66, 6762-6771. [CrossRef]

40. Huang, W.D.; Sherman, B.T.; Lempicki, R.A. Systematic and integrative analysis of large gene lists using DAVID bioinformatics resources. Nature Protoc. 2009, 4, 44-57. [CrossRef] [PubMed]

41. Atkinson, W.; Lockhart, S.; Whorwell, P.J.; Keevil, B.; Houghton, L.A. Altered 5-Hydroxytryptamine signaling in patients with constipation- and diarrhea-predominant irritable bowel syndrome. Gastroenterology 2006, 130, 34-43. [CrossRef]

42. Brand, T.; Anderson, G.M. The measurement of platelet-poor plasma serotonin: A systematic review of prior reports and recommendations for improved analysis. Clin. Chem. 2011, 57, 1376-1386. [CrossRef]

43. Stoeger, V.; Holik, A.K.; Hölz, K.; Dingjan, T.; Hans, J.; Ley, J.P.; Krammer, G.E.; Niv, M.Y.; Somoza, M.M.; Somoza, V. Bitter-Tasting Amino Acids 1-Arginine and 1-Isoleucine Differentially Regulate Proton Secretion via T2R1 Signaling in Human Parietal Cells in Culture. J. Agric. Food Chem. 2020, 68, 3434-3444. [CrossRef]

44. Johnston, K.; Lu, Z.; Rudd, J. Looking beyond 5-HT3 receptors: A review of the wider role of serotonin in the pharmacology of nausea and vomiting. Eur. J. Pharmacol. 2014, 722, 13-25. [CrossRef] [PubMed]

45. Sentani, K.; Oue, N.; Noguchi, T.; Sakamoto, N.; Matsusaki, K.; Yasui, W. Immunostaining of gastric cancer with neuroendocrine differentiation: Reg IV-positive neuroendocrine cells are associated with gastrin, serotonin, pancreatic polypeptide and somatostatin. Pathol. Int. 2010, 60, 291-297. [CrossRef] [PubMed] 
46. Van Lelyveld, N.; Linde, J.T.; Schipper, M.E.; Samsom, M. Regional differences in expression of TPH-1, SERT, 5-HT(3) and 5-HT(4) receptors in the human stomach and duodenum. Neurogastroenterol. Motil. 2007, 19, 342-348. [CrossRef] [PubMed]

47. Yu, P.L.; Fujimura, M.; Hayashi, N.; Nakamura, T.; Fujimiya, M. Mechanisms in regulating the release of serotonin from the perfused rat stomach. Am. J. Physiol. Gastrointest. Liver Physiol. 2001, 280, G1099-G1105. [CrossRef]

48. Liszt, K.I.; Hans, J.; Ley, J.P.; Kock, E.; Somoza, V. Characterization of bitter compounds via modulation of proton secretion in human gastric parietal cells in culture. J. Agric. Food Chem. 2018, 66, 2295-2300. [CrossRef] [PubMed]

49. Mattson, M.P. Hormesis defined. Ageing Res. Rev. 2008, 7, 1-7. [CrossRef]

50. Van Lelyveld, N.; Linde, J.T.; Schipper, M.; Samsom, M. Serotonergic signalling in the stomach and duodenum of patients with gastroparesis. Neurogastroenterol. Motil. 2008, 20, 448-455. [CrossRef]

51. Racke, K.; Reimann, A.; Schworer, H.; Kilbinger, H. Regulation of 5-HT release from enterochromaffin cells. Behav. Brain Res. 1996, 73, 83-87. [CrossRef]

52. Ruijter, J.M.; Ramakers, C.; Hoogaars, W.M.; Karlen, Y.; Bakker, O.; Van den Hoff, M.J.; Moorman, A.F. Amplification efficiency: Linking baseline and bias in the analysis of quantitative PCR data. Nucleic Acids Res. 2009, 37, e45. [CrossRef] [PubMed]

53. Sack, M.; Hölz, K.; Holik, A.-K.; Kretschy, N.; Somoza, V.; Stengele, K.-P.; Somoza, M.M. Express photolithographic DNA microarray synthesis with optimized chemistry and high-efficiency photolabile groups. J. Nanobiotechnol. 2016, 14, 14. [CrossRef] [PubMed]

54. Senin, L.L.; Al-Massadi, O.; Folgueira, C.; Castelao, C.; Pardo, M.; Barja-Fernandez, S.; Roca-Rivada, A.; Amil, M.; Crujeiras, A.B.; Garcia-Caballero, T.; et al. The gastric CB1 receptor modulates ghrelin production through the mTOR pathway to regulate food intake. PLoS ONE 2013, 8, e80339. [CrossRef] [PubMed] 